\title{
The effect of doxepin on Bacillus subtilis and Pseudomonas aeruginosa.
}

\author{
Mostafa Norizadeh Tazehkand*
}

Department of Pharmaceutical Biotechnology, Faculty of Pharmacy, Bulent Ecevit University, Zonguldak, Turkey

\begin{abstract}
Doxepin is a tricyclic antidepressant (TCA) used as a pill to treat major depressive disorder, anxiety disorders, chronic hives, and for short-term help with trouble remaining asleep after going to bed (a form of insomnia). As a cream it is used for short term treatment of itchiness due to atopic dermatitis or lichen simplex chronicus. The aim of the present study was to in vitro evaluate the antibacterial effects of doxepin using MIC, MBC and disk diffusion methods.

The MIC and MBC was determined by dilution assay using different concentrations of doxepin on Bacillus subtilis and Pseudomonas aeruginosa. Disk diffusion assay were prepared under sterile conditions disks of drugs (three repeat for each concentration) containing three different doses $(25,50$ and $150 \mu \mathrm{g})$ were prepared.

MIC values of doxepin against Pseudomonas aeruginosa was $0.750 \mathrm{mg} / \mathrm{ml}$, and $\mathrm{MBC}$ values was 4.5 $\mathrm{mg} / \mathrm{ml}$ and MIC values of doxepin on Bacillus subtilis was $0.500 \mathrm{mg} / \mathrm{ml}$, and MBC values was 4.5 $\mathrm{mg} / \mathrm{ml}$. The results obtained from disk diffusion assay supported that the doxepin has not antibacterial effect against Pseudomonas aeruginosa and Bacillus subtilis. It can be said that doxepin does not have antibiotic effect against gram negative and gram positive bacterial strain.
\end{abstract}

Keywords: Antibacterial effects, Doxepin, Pseudomonas aeruginosa, Bacillus subtilis.

Accepted on 28 March, 2018

\section{Introduction}

Depression (major depressive disorder) is a common and serious medical illness that negatively affects how you feel, the way you think and how you act. Fortunately, it is also treatable. Depression causes feelings of sadness and/or a loss of interest in activities once enjoyed. Many types of antidepressant medications are available to treat depression. Doxepin is one of these antidepressant drugs that use for major depressive disorders. Doxepin is a tricyclic antidepressant with a tertiary amine, inhibits the reuptake of serotonin and norepinephrine exerts a very low inhibition of dopamine reuptake. Doxepin is active metabolite of desmethyldoxepin (nordoxepin), has also antidepressant effects [1-3]. Doxepin was approved by the FDA in 2010 and is indicated for the treatment of insomnia characterized by difficulties with sleep maintenance. Doxepin sorely binds to $\mathrm{H} 1$ and $\mathrm{H} 2$ (histamine) receptors and selective histamine antagonistic function is accountable for the drug's sleep-promoting properties [4-6]. It also has some antagonistic influences on 5-HT receptors, and muscarinic cholinergic receptors and alpha1 adrenergic receptors. In our life, doxepin is going become a promising contestant for inflammatory and pain conditions specifically in patients with depressive disorder [7]. Patients who take cimetidine and doxepin together should not take more than $3 \mathrm{mg}$ of doxepin per day. Low-dose of doxepin does not affected by other drugs that affect the cytochrome P450 system. When given nightly for up to three months, the $3 \mathrm{mg}$ concentration produces consistent results without causing next day residual effects on cognitive performance [8]. No evidence of carcinogenic potential was observed when doxepin was treated orally to mice for 26 weeks at concentration of $25,50,75$ and $100 \mathrm{mg} / \mathrm{kg} /$ day. On the other hand researcher reported that doxepin has not shown oncogenic effect when treated daily to rats for 104 weeks at doses of 10 , 30 and $75 \mathrm{mg}$ (Trademark of Pernix Therapeutics LLC, 2012).

The antimicrobial activity of doxepin againts Bacillus subtilis and Pseudomonas aeruginosa has not been examined yet and therefore this study was aimed to assess this effect on two bacterial strains.

\section{Materials and Methods}

\section{Chemicals}

In this study, the test substance, doxepin, was purchased from Razavi and its properties and molecular structure is shown in Figure 1.<smiles>CN(C)CC/C=C1\c2ccccc2COc2ccccc21</smiles>

Figure 1. The structure of doxepin.

Trade names: Sinequan

Synonyms: NSC-108160

MedlinePlus: a682390

License data: US FDA, Doxepin

ATC code: N06AA12 (WHO) 
Bioavailability: 13-45\% (mean 29\%)

Protein binding: $76 \%$

Metabolism: Hepatic (CYP2D6, CYP2C19)

Biological half-life: Doxepin: 8-24 hours (mean 17 hours)

CAS Number: 1668-19-5

\section{Formula: $\mathrm{C} 19 \mathrm{H} 21 \mathrm{NO}$}

Molar mass: $279.376 \mathrm{~g} / \mathrm{mol}$.

In this study, Mueller Hinton agar, Mueller Hinton broth were purchased from Sigma, Antimicrobial Susceptibility Disks purchased from Merck. All test solutions were freshly prepared prior to each experiment.

\section{Microorganisms}

In this research antimicrobial effect of doxepin were tested against Bacillus subtilis as a gram positive bacteria and Pseudomonas aeruginosa as Gram negative bacteria. The tested bacterial strains were obtained from Pamukkale University (Bacteriology Lab) and Bulent Ecevit University (Medical Microbiology Lab). Both bacterial strains were cultured in Mueller-Hinton Agar and overnight incubation at $37^{\circ} \mathrm{C}$.

Bacillus subtilis is a Gram-positive, catalase-positive bacterium, found in soil and the gastrointestinal tract of ruminants and humans. Bacillus subtilis has rod-shaped and can form a tough, protective endospore, allowing it to tolerate extreme environmental conditions Bacillus subtilis is considered the best studied gram positive bacterium and cell differentiation [9].

Pseudomonas aeruginosa is a gram-negative, rod-shaped bacteria that can cause disease in plants and animals, including humans. Some subtype of Pseudomonas aeruginosa has multidrug resistant, its intrinsically advanced antibiotic resistance mechanisms, and its association with serious illnesses-hospital-acquired infections such as ventilatorassociated pneumonia and various sepsis syndromes [10-12]. Pseudomonas aeruginosa typically infects the airway, urinary tract, burns, and wounds, and also causes other blood infections [13].

\section{Determination of minimum inhibitory concentration (MIC) and minimum bactericidal concentration $(M B C)$ of doxepin}

In this study each bacterial strain was individually grown in test tubes containing $4 \mathrm{~mL}$ of Müller Hinton broth for overnight at $37^{\circ} \mathrm{C}$. The minimum inhibitory concentration (MIC) and minimum bactericidal concentration (MBC) of doxepin were assessed against Bacillus subtilis and Pseudomonas aeruginosa using the microdilution method. Serial dilutions of doxepin with final concentrations ranging from 6.25 to $6400 \mu \mathrm{g} \mathrm{mL}^{-1}$. The diluted samples $(3.9 \mathrm{ml})$ were transferred to different tubes and mixed well with vortex. So, a microbial suspension of $0.5 \mathrm{McF}$ arland of bacterial strains (100 $\mu 1)$ were added to Mueller Hinton broth containing different doxepin concentrations tubes. In order to, the control sample contained sterile water with inoculum were prepared too. The inoculated tubes were incubated at $37^{\circ} \mathrm{C}$ for 24 hours. All assays were performed in triplicate. Visual observation of bacterial growth was performed after $24 \mathrm{~h}$ of incubation at $37^{\circ} \mathrm{C}$. MIC values were identified as the minimum concentration at which no visible bacterial growth was recorded.

Minimum bactericidal concentration (MBC) of doxepin were determined by inoculating the assay mixtures from the samples showing no microbial growth onto the sterile Mueller Hinton agar medium. The plates were incubated at $37^{\circ} \mathrm{C}$ for 24 hours. The presence of microbial growth on the medium indicated that the doxepin possessed bacteriostatic activity, while the absence of the growth implied bactericidal activity of the doxepin samples.

The disk diffusion assay is used to evaluate antibacterial effect of doxepin against Bacillus subtilis and Pseudomonas aeruginosa. $20 \mathrm{ml}$ of Mueller-Hilton agar culture medium was poured into sterile plastic Petri dishes previously inoculated with two bacterial suspensions. The doxepin $(25 \mathrm{mg})$ were dissolved in $10 \mathrm{ml}$ of $10 \%$ methanol and sterilized through Millipore filter $(0.22 \mu \mathrm{m})$ then loaded over sterile filter paper discs ( $8 \mathrm{~mm}$ in diameter) to obtain final concentration of 12.5, 25 and $100 \mu \mathrm{g} /$ disc. Sterile discs loaded with different doxepin concentration $(12.5,25$ and $100 \mu \mathrm{g} /$ disc) were placed on the Mueller-Hilton agar plates. In order to, discs loaded with $20 \mu \mathrm{g}$ of sterile water was used as untreated control. The plates were incubated at $37^{\circ} \mathrm{C}$ for 24 hours. The presence of inhibition zones were measured, recorded and considered as indication for antimicrobial activity $[14,15]$.

\section{Result}

The minimum inhibitory concentration (MIC) and minimum bactericidal concentration (MBC) of doxepin were tested by serial dilution method. Different concentrations of doxepin $(6.25$ to $6400 \mu \mathrm{g})$ were tested in our research.

MIC values of doxepin on Bacillus subtilis was $200 \mu \mathrm{g} / \mathrm{ml}$, and MBC values was $1600 \mu \mathrm{g} / \mathrm{ml}$ and MIC values of doxepin against Pseudomonas aeruginosa was $400 \mu \mathrm{g} / \mathrm{ml}$, and MBC values was $3200 \mu \mathrm{g} / \mathrm{ml}$.

For determination of antibacterial activity of doxepin on two bacterial strain were tested by disc diffusion assay. So, different doxepin concentrations $(12.5,25$ and $100 \mu \mathrm{g})$ were selected for disk diffusion assay. The result of disc diffusion assay are shown in Figures 2 and 3.The result of this study showed that doxepin has not antibacterial effect on Bacillus subtilis and Pseudomonas aeruginosa, because diameter of inhibition zone at all concentration of doxepin was zero $\mathrm{mm}$. 


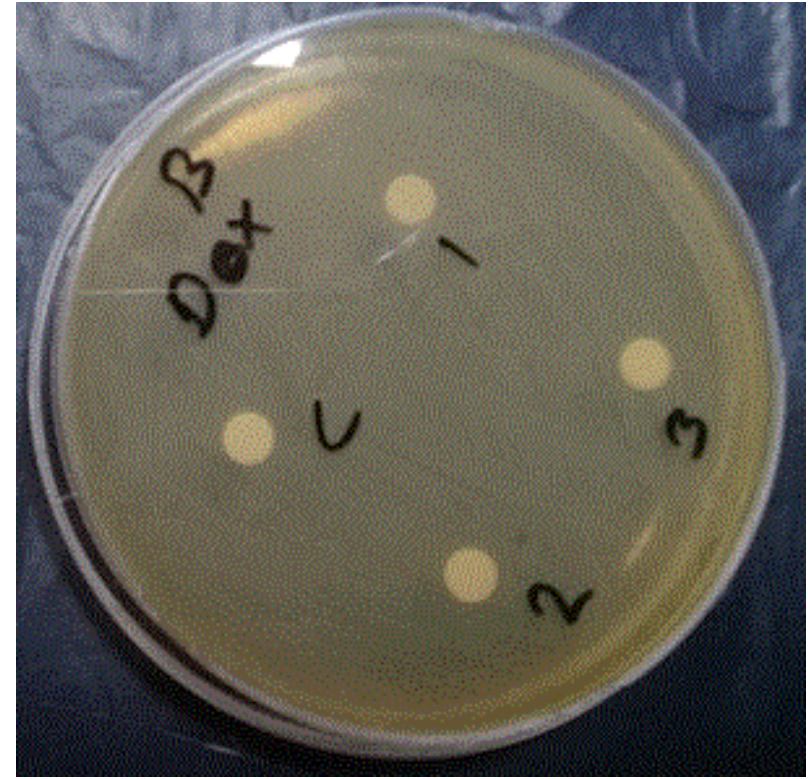

Figure 2. Antibacterial effect of doxepin on Bacillus subtilis (C: Control, 1: 12.5, 2: 25 and 3: $50 \mu \mathrm{g}$ ).

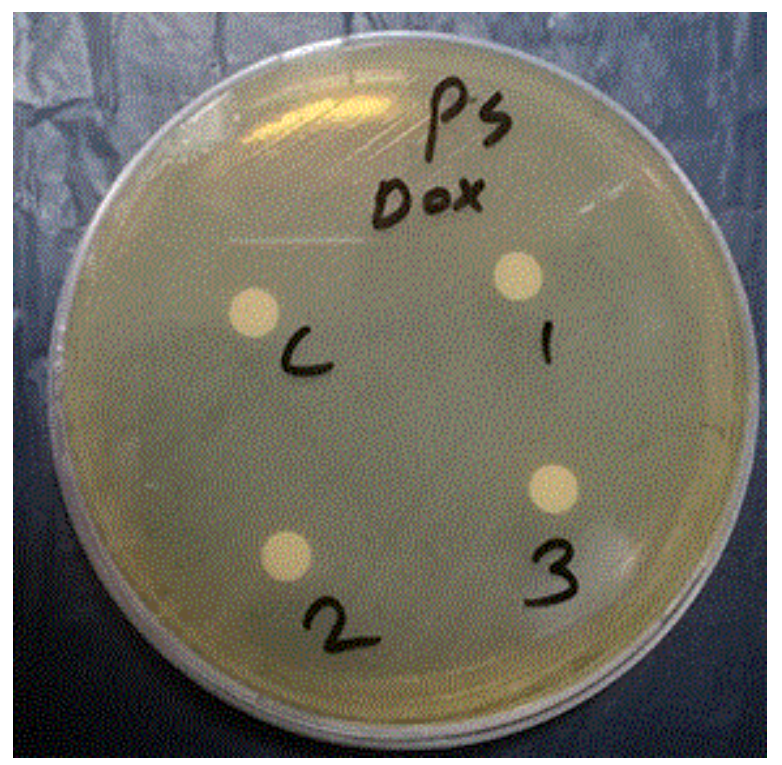

Figure 3. Antibacterial effect of doxepin on Pseudomonas aeruginosa (C: Control, 1: 12.5, 2: 25 and 3: $50 \mu \mathrm{g}$ ).

\section{Discussion}

According to our knowledge, this is the first study that addresses the antimicrobial activity of doxepin on Bacillus subtilis and Pseudomonas aeruginosa. According to findings of this research, doxepin has not antibacterial effect against Bacillus subtilis and Pseudomonas aeruginosa. Doxepin is one of the most common antidepressant using for treatment of major depressive disorders.

MTT assay, Micronuclei, Sister Chromatid Exchanges, Chromosome Aberration, DNA breaking assay and antibacterial activity test are methods for study of risk and protective effect of substances or drugs [16-18].
In accordance with this result some of the antidepressant drugs were not genotoxic effect on human cells were not antibacterial effect on bacterial strains. For example, Kalayci et al. showed that venlafaxine and alprazolam don't have antibacterial effect on gram positive and gram negatice bacterial strains [19]. Norizadeh tazehkand and Topaktas reported that remeron does not have genotoxic effect on peripheral blood lymphocyte [16]. Similar results observed by Ponsa et al. [20] who found no evidence of increased frequency of micronuclei, sister chromatid exchanges or chromosome aberrations induced by MPH (Methylphenidate) in children and adult populations. The other study showed citalopram did not have carcinogenic activity in long term oral administration of mice and rats at doses up to $40 \mathrm{mg} / \mathrm{kg} /$ day [21]. In contrast to doxepin, some of reviews concerning the toxicity, antibacterial effect and mutagenicity of other antidepressant drugs have been published. For example, Mandal et al. reported that amitriptyline hydrochloride exhibited significant action against both Gram positive (Staphylococcus saprophyticus VS14, Staphylococcus citreus M1, Staphylococcus lactis 309) and Gram negative bacterial strains (Shigella boydii 9E16552, Salmonella virchowATCC3.1, Salmonella derby ATCC 3.2) [22]. On the other hand, researcher showed that sertralin has antibacterial effect against gram positive bacteria [23]. Saito et al. [24] who found that in Chinese hamster 79 cells, bupropion hydrochloride caused DNA single strand breaks and decrease in the DNA and RNA content. In addition, Jefferson et al. [25] observed that bupropion produced positive response (2 to 3 times control mutation rate) in 2 of 5 strains in the Ames bacterial mutagenicity test $[26,27]$.

\section{Conclusion}

In this research doxepin did not show that antibacterial effect on gram negative and geram positive bacterial strains. Therefore, it can be concluded that doxepin might not pose a potential risk for our bacterial flora. However, further in vivo and in vitro studies are required to provide reliable data about the use of doxepin as an antidepressant for treatment of major depressive disorders.

\section{Declaration of Interest}

The authors report no conflicts of interest. The authors alone are responsible for the content and writing of this article.

\section{References}

1. Shibuya K, Funaki Y, Hiraoka K. Doxepin binding to histamine $\mathrm{H} 1$ receptors in living human brain: reproducibility during attentive waking and circadian rhythm. Front Syst Neurosci. 2012;6:45.

2. Ahles S, Gwirtsman H, Halaris A. Comparative cardiac effects of maprotiline and doxepin in elderly depressed patients. J Clin Psychiatry. 1984;45:460-5.

3. Shimamura T, Shiroishi M, Weyand S. Structure of the human histamine $\mathrm{H} 1$ receptor complex with doxepin. Nature. 2011;475:65-70. 
4. Hinze-Selch D, Schuld A, Kraus T. Effects of antidepressants on weight and on the plasma levels of leptin TNF-alpha and soluble TNF receptors: A longitudinal study in patients treated with amitriptyline or paroxetine. Neuro Psycho Pharmacology. 2000;23:13-9.

5. Hajhashemi V, Sadeghi H, Minaiyan M. The role of central mechanisms in the anti-inflammatory effect of amitriptyline on carrageenan induced paw edema in rats. Clinics (Sao Paulo). 2010;65:1183-7.

6. Hauser W, Schmidt C, Stallmach A. Depression and mucosal proinflammatory cytokines are associated in patients with ulcerative colitis and pouchitis - a pilot study. J Crohns Colitis. 2011;5:350-3.

7. Janssen D, Caniato R, Verster J. A psycho neuro immunological review on cytokines involved in antidepressant treatment response. Hum Psycho Pharmacol. 2010;25:201-15.

8. Dhiren K, Patel Dhiren K, Patel Jennifer D. Doxepin (Silenor) for Insomnia. American Family Physician. 2011;84:453-4.

9. Pepe O, Blaiotta G, Moschetti G. Rope-producing strains of Bacillus spp. from wheat bread and strategy for their control by lactic acid bacteria". Appl Environ Microbiol. 2003;69:2321-9.

10. Balcht A, Smith R. Pseudomonas aeruginosa: Infections and Treatment. Informa Health Care. 1994;83-4.

11. Itah A, Essien J. Growth Profile and Hydrocarbonoclastic Potential of Microorganisms Isolated from Tarballs in the Bight of Bonny Nigeria. World J Microbiol Biotechnol. 2005;21:1317-22.

12. Høiby N, Ciofu O, Bjarnsholt T. Pseudomonas aeruginosa biofilms in cystic fibrosis. Future Microbiology. 2010;5:1663-74.

13. Todar's Online Textbook of Bacteriology. 2004.

14. Mariselvam RA, Ranjitsingh Nanthini JA, Kalirajan K. Green synthesis of silver nanoparticles from the extract of the inflorescence of Cocos nucifera (Family:Arecaceae) for enhance antibacterial activity. Spectrochimica Acta Part A: Spectrochim Acta A Mol Biomol Spectrosc. 2014;129:537-41.

15. Yehia RS, Al-Sheikh H. Biosynthesis and characterization of silver nanoparticles produced by Pleurotus ostreatus and the iran ticandidal and anticanceractivities. World $\mathrm{J}$ Microbiol Biotechnol. 2014;30:2797-803.

16. Norizadeh Tazehkand, Topaktas M, Yilmaz M, et al. Delineating the antigenotoxic and anticytotoxic potentials of 4-methylimidazole against ethyl methanesulfonate toxicity in bone marrow cell of swiss albino mice. Bratisl Lek Listy. 2016;117:290-4.

17. Norizadeh Tazehkand M, Topaktas $M$. The in vitro genotoxic and cytotoxic effects of remeron on human peripheral blood lymphocytes. Drug Chem Toxicol. 2015;38(3):266-71.

18. Norizadeh Tazehkand M. Antiproliferative effect of a food coloring on colon cancer cell line. Bratisl Lek Listy. 2017;118:265-8.

19. Kalayc1 S, Demirci S, Şahin F. Antimicrobial Properties of Various Psychotropic Drugs Against Broad Range Microorganisms. Current Psycho Pharmacology. 2014;3:195-202.

20. Ponsa I, Ramos-Quiroga, JA Ribase's M. Absence of cytogenetic effects in children and adults with attentiondeficit/ hyperactivity disorder treated with methylphenidate. Mutat Res. 2009;666:44-9.

21. Croom KF, Plosker GL. Spotlight on the pharmaco economics of escitalopram in depression. CNS Drugs. 2004;8:469-73.

22. Mandal A, Sinha C, Jena AK. An Investigation on in vitro and in vivo Antimicrobial Properties of the Antidepressant: Amitriptyline Hydrochloride. Braz J Microbiol. 2010;41:635-45.

23. Coban AY, Tanriverdi Cayci, Y Keleş, Uludağ S. Investigation of antibacterial activity of sertraline. Mikrobiyol Bul. 2009;43:651-6.

24. Saito K, Mita S, Kamataki T. DNA single strand breaks by bupropion hydrochloride and related compound in chinese hamster V79 cells. Cancer Let. 1984;24:121-7.

25. Jefferson TW, John AR, Nelson JN. The effect of bupropion in the Ames test. J Clin Psychiatry. 2006;67:865-73.

26. Tazehkand MN, Hajipour O, Moridikia F, et al. Investigation of anticarcinogenic and antioxidant effects of -methylimidazole. Bratisl Lek Listy. 2017;118:149-52.

27. Tazehkand MN, Moridikia A, Hajipour O, et al. The effects of 4-MEI on cell proliferation DNA breaking and DNA fragmentation. Bratisl Lek Listy. 2016;117:371-5.

\section{* Correspondence to:}

Mostafa Norizadeh Tazehkand

Department of Pharmaceutical Biotechnology

Faculty of Pharmacy

Bulent Ecevit University

Zonguldak

Turkey

E-mail: mostafa.norizadeh@beun.edu.tr

Tel: +90 3722911100 